\title{
Fences and Border Protection: The Question of Establishing Technical Barriers in Europe
}

\author{
János BESENYŐ ${ }^{1}$
}

\begin{abstract}
The security environment of the $21^{\text {st }}$ century confronted the international community with unprecedented challenges. One could say that we are only facing current negative trends with slowly evolving responses. However, these statements seem to contradict some facts that prove, that although there are deficient aspects to the current security structures, we are able to effectively handle many of the national and international challenges. Over the centuries, installation of various walls, wall systems have repeatedly defended the integrity of an area, the community of people living there from armed groups or offensive units. We can also find examples where population movements and bilateral territorial conflicts weakened-the relatively stable - great powers, which in order to avoid further intrusion and considerable social changes, designed a so-called "buffer zone" on their external borders to defend their sovereignty. There is no question that the current border restriction processes try to rehabilitate a long-time frequently used scheme for the protection of nationals, which was in recent times burdened by sad associations, such as the Berlin Wall. This is proven by the fact that only since 2000, more than 25 walls were built for security purposes. In my analysis, considering the present processes, I highlight the security challenges of $21^{\text {st }}$ century Europe and the tightened border security measures generated by the fears and threats. I also stress the impact of the recent wave of migration in the transit states' and western countries' security system, as well as outline the activities of the Eastern European and Baltic states in response to the deteriorating relationship with Russia.
\end{abstract}

Keywords: migration, border fence, border security, Europe, Ceuta and Mellila, Calais Jungle, southern closing of borders

\section{Historical Background}

Considering Europe's past, the wall which served various purposes during the reign of the Roman Emperor Trajan (28 $8^{\text {th }}$ January, $98-8^{\text {th }}$ August, 117) back during the Roman Empire was among the first defence systems in the world. [1: 4-9] The limes was gradually built and modified from the first century onward. The approximately 3,000 kilometres line initially served as a military logistics road, but over the decades it was reinforced to become a complete border-defence installation. The Roman Empire and its values were defended by a wall system consisting of three elements, as well as increased natural boundaries and "manpower supervision”. The first stage of the structure was a mound of earth and a hedge fence, later

1 Colonel, Ph.D., Hungarian Defence Forces (HDF) General Staff Scientific Research Center; e-mail: besenyo. janos@hm.gov.hu 
this form was reinforced with stone walls. Invasions by barbarians ${ }^{2}$ were hindered also by a ditch system built on both sides, as well as frequent watchtowers. [2: 26-34] Although the primary purpose of the limes was much more to highlight the cultural divide rather than to exclude a direct threat. Hadrian, in 122, ordered - in fact, according to sources built with his own strength-the 120-kilometre long, 4.5-meter high and 3-meter wide physical barriers, with watchtowers, specifically against the non-defeated Barbarians. [1: 4-9] [1: 11] [1: 59] In terms of effectiveness, there is no question that the high level of protection contributed to the gradual formation of today's civilization, culture, religion and politics, our western values and identity.

In the Asian continent, we may find older samples for the merger of defence lines and trade routes. The multi-staged Great Wall of China began to be built in 400 B.C., including ramparts, the increasingly stable and monumental fortification was built until the $14-17^{\text {th }}$ century. The visitable parts were mostly made during the Ming Dynasty (1368-1644). The approximately 7,897-kilometre long wall's height is 10 meters, its width 5 to 8 meters. The purpose of setting it up was on one hand to protect the Silk Road where outstanding trade took place, to protect the economic interests of China, one of the most flourishing Asian cultures and to assure its cultural and social power. [3: 9-28]

Three centuries after the reign of the Ming Dynasty another version of the partition walls separating two areas - the German Democratic Republic (GDR) and the Federal Republic of Germany (FRG) - were set up. The Berlin Wall sliced in half western and eastern parts of the city between 1961 and 1989, for almost three decades. The total length was 156.4 kilometres, of which 43.7 kilometres lay directly between the two German parts. The structure's fortification dynamically followed the stages of the bipolar confrontation. The initial simple barbed wire barrier continuously expanded and eventually grew to become a fortress in line with the intensification of estrangement. The wall in the final stage was a 3.5-meter high and 1-meter wide barrier, with watchtowers, minefields and ditch system reinforced as the second defence line, all these claimed the lives of about two hundred individuals. [4] The memory of the Berlin Wall, the Second World War and the associations with subsequent instability left a deep impression on the population of Europe. The legacy of hermetically separated families, political and military instructions caring little with human lots are reflected in the current security situation as well. At the same time, we must recognize that parallels between the circumstances of the Berlin Wall and the current migration challenges are irrelevant. The similarity of the Berlin Wall and the current structures is only in that they aim to close the borders in order to conserve the current social structure.

The memory of the Berlin Wall and the separation between the communist East and the "capitalist” West presented some deterrent effect for the construction of similar barriers in Europe, while in the rest of the world, these protection systems were used in response to multidimensional security challenges. As a result of globalization, financial and commercial transactions increasingly blurred the physical borders of states. In accordance with changes in terms of travel limitations, more and more people reached remote continents. Simultaneously with the expanding travel conditions, intractable social and domestic political processes were launched across the Middle East and Africa. The security situation was worsened by the influx of weaponry, technological innovations affecting the defence industry and infor-

2 The Romans called everyone barbaric who did not live in the empire, and did not embrace the culture. This term did not yet carry a negative connotation, it simply served to distinguish the Romans and other peoples. 
mation technology, as well as the often "too advantageous" image of the West in the media. Western states were reflected as a kind of paradise for the inhabitants, which the migrant population sooner or later wished to "conquer", or at least benefit of its means. This desire placed increasing migratory pressures on the western states, which they were not able to fully handle. Therefore, increased surveillance and border protection has become very important, although this was contrary to the liberal values of Western civilization. The $11^{\text {st }}$ September, 2001, terrorist attacks though highlighted the high vulnerability of these societies. As a result of the change in US foreign policy, increased security measures were applied for guaranteeing the security and power of the nation.

Simultaneously with these processes, most of the continents of the world built a buffer zone with barriers and a variety of advanced tools. Even if some have almost only symbolic value, among the installations many play a decisive role even nowadays. ${ }^{3}$ [5] Tightened border-protection has become a commonly used tool ${ }^{4}$ [6] [7] that was further enhanced by migration pressure-peaking in the summer of 2015, coming from the Middle East and Africa-as well as the sharpening Ukrainian conflict. ${ }^{5}$ [8] As a result, currently 65 wall systems operate in the world. [9]

In order to maintain security and curb illegal immigration a decision was made to close the borders and tighten border controls in several European countries. In the following chapters I intend to present these examples in chronological order, highlighting the need for the closure of the southern border of Hungary and the common characteristics of European border security provisions.

\section{Ceuta and Mellila, the European Union and Africa's Legal Borders}

Ceuta and Melilla have experienced migratory pressure since the early 1990s. The first settlement came under Portuguese rule in 1415, and on $1^{\text {st }}$ January, 1668, Portuguese King Alfonso VI officially handed over the city to the Spanish monarch, Charles II, who, in turn, acknowledged Alfonso's rule over Portugal. Melilla was occupied by Spanish troops as part of a campaign launched in 1496. [10: 99-101] [11: 77] [12: 37]

When Morocco became independent (1956), the two cities remained under Spanish rule as its exclave, so when the country joined the European Union, the settlements were the southernmost boundary of the integration. Considering their geographical situation, it seemed easier for migrants to get to Europe, rather than to set out on a much more dangerous Mediterranean Sea journey. Additionally, those migrants who arrived in one of the two cities, according to the formal system, the rules of the European Union (including the highly-cited Dublin III regulation on the admission of refugees and rules of their treatment) apply. Therefore, the cities had to face a growing influx of immigrants in the 1990s, hence in 1993, Ceuta

3 As an example, I could mention, the border between Pakistan and India, which is being upgraded by the opposing parties continuously.

4 The latest walls include the common border wall of Somalia and Kenya, with which Kenya aims to guard against infiltration of Al-Shabab and other terrorist groups from Somalia, similarly to Tunisia, who began reinforcing the border with Libya.

5 Influencing process also involve the weak economic and employment opportunities in the Middle East and Africa, the presence and activities of terrorist organizations in the region, activity of the various armed groups, organized crime or the formation of the attractive, but not always realistic Europe picture. 
erected an 8.2-kilometre long, 3-meter high fence. Since that was relatively easy to overcome for migrants, in 1995, the city further strengthened the height to six meters. [13] The migrants turned to Melilla, so in December 1996, the city built a 12-kilometre long, three-meter high fence. Thereby both exclaves closed the southern borders of the European Union with a physical barrier.

The construction cost about EUR 60 million, funded in part by EU grants. In 2006, the Union allocated a further EUR 40 million to Morocco for the efficient management of the migration crisis, by which the fences were expanded with additional elements (such as motion detection systems). [14:13-48] Including this amount of aid, between 2007 and 2010, Spain spent the largest amount - among the member states — of sums to be allocated for protection (EUR 120 million in total). [15] Three parallel fence lines defend the exclave's frequently besieged borders, it reaches a height of 6 meters, with occasional roll-wire lines, infrared motion sensors and CCTV cameras. In addition, the effectiveness of protection was further increased by the use of manpower, because police—-500 guards per shift—are on duty along the fence. [14] The situation of Ceuta and Melilla became particularly problematic on several occasions during the 2014-2015 crisis, combined with news about acts of smuggling and organized criminal activity.

Not far from the Moroccan border, migrants prepare for the climb over the 6-meter high fence while residing in crowded refugee camps. During that time, they collect sufficient financial backing to cover the sums for the route from the exclaves to Europe. Moroccan authorities are trying to control the activity of organized criminal groups and suppress the activities of people smugglers, during which it is not uncommon that they physically abuse refugees. [16: 45] In spite of these facts, many people are still trying to get over the fence every year, as it is shown in the figure below.

Table 1. Number of illegal migrants, Ceuta and Mellila (2000-2016). [42]

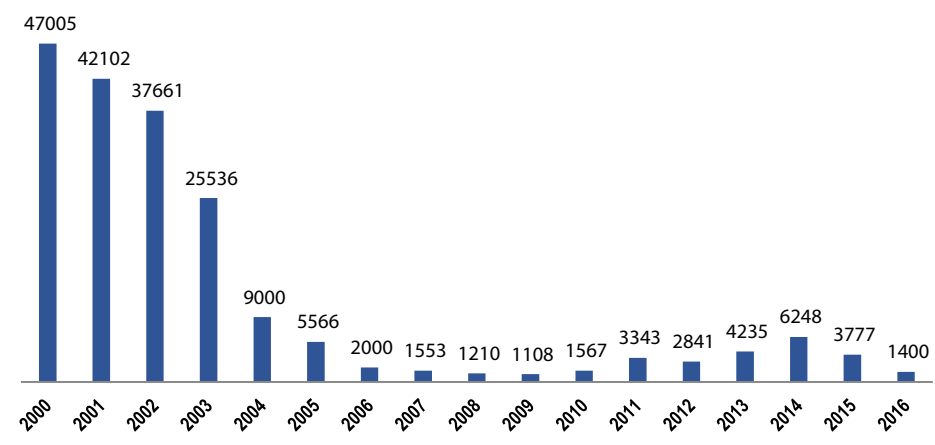

\section{Greece - Turkey}

In 2012, to relieve the already perceptible migration pressure, Greek authorities also closed their shared border with Turkey, where a fence was built, which is located in the Evros river valley, lying 10.5 kilometres in length. [17]

In November 2012, Greece also completed a 4-meter high fence system consisting of six serial barbed wire lines with thermal sensor cameras and continuous patrol service. An im- 
portant difference compared to Ceuta and Mellila is that a simple line of barbed wire placed in a cylindrical column is not really much in depth, thereby getting close to the fence is easier. Countering this, Greek authorities have set up two lines of fencing system. One runs directly on the border, the other lies on the territory of Greece. The fence has a concrete foundation, it is well-built suggesting a longer-term maintenance intent. The security system was set up within the framework of the Frontex's ${ }^{6}$ operation ASPIDA. ${ }^{7}$ [18]

In addition to the construction of the fence, Greek authorities strictly checked Patra and Igoumenitsa ports, forcing migrants to travel further to Italy or other European countries. The operation was very successful, as the number of captured illegal border crossers declined from 2,000 people per week in August 2012, to 10 per week in October 2012. [19] Therefore, in 2013, the then Greek Defence Minister Dimitris Avramopoulos said that the government's decisive acts are demonstrated by the results, because illegal migration has been almost completely wiped out from the territory. ${ }^{8}$ [20] However, we must add that the increasing level of illegal immigration phenomenon was not stopped by tightening of border protection, but its route changed, the centre of gravity shifted to the Aegean Sea, and some of the migrants tried to get to Europe not over the Greek, but the Bulgarian border.

\section{Bulgaria, Turkey}

In 2012, only 1,700 migrants arrived illegally in Bulgaria, but the number in 2013, increased to 11,158 people, so the government decided to build a fence system on the Southeast borders with Turkey. [17] The decision was made after a significant increase in the number of arrivals, mainly from Syria in 2013. The majority of Syrians arrived via Turkey to Bulgaria, from where they progressed further through the Eastern Mediterranean route. The closing of borders, therefore, was necessary because of guiding migratory pressures and to discourage illegal border crossings. [21] The construction plans were announced in November 2013. The plans included a 166-kilometre long fence system designed for the country's border with Turkey, in Yambol county. Until 2015, 33 kilometres, [22] until March 2016, a 100-kilometre long section was set up on the border. As for the structural conditions, the razor wire fence is 3-meter high, embedded in concrete columns and further strengthened by a camera system used in the previously mentioned borders as well. ${ }^{9}$ [17]

At the same time border control was further secured, 1,572 police officers and 141 SUVs were reallocated for the routes most used by migrants. Additionally, they strengthened their cooperation with the Turkish border agencies as well. The effectiveness of the fence has been demonstrated since 2014, compared to the previous year, and according to Frontex data, in the first quarter of 2016, compared to the previous year, the number of illegal migrants decreased by $84 \%$. [23: 10] Because of the success and the persistent migrant pressure, the Bulgarian leadership decided and started to construct a new fence on the Greek-Bulgarian border as well. [24]

6 The EU's border security agency, set up in 2005.

7 The mandate of the operation ASPIDA was to defend the sea borders of Europe and intercept the illegal border crossings on the Greek-Turkish border.

8 At the same time in the Spring of 2016, as the EU Commissioner for Refugees he condemned the European states building fences, claiming that the "closing of borders is not the solution for the migrant crisis."

9 The Bulgarian system was mainly set up by the financial help of the EUROSUR - The European Border Surveillance System. 


\section{Great-Britain}

Britain built a security fence in northern France near Calais, at the entrance of the "Eurotunnel” in November 2014. The cause was primarily the gradually growing number of migrants since 1999, from France. The Calais “jungle”, the nickname for the refugee camp, became overloaded, and the law enforcement bodies gradually lost their influence. As a result, the camp already presented a major security challenge for the two countries. [25] While the leadership of London argued that the problem should be solved by the French, in September 2014, they offered to help by setting up the fence system. The British political leadership thought this kind of defence infrastructure would be able to stop the growing number of refugees and redirect them to the border crossing stations. [26]

The fence was built in November 2014, but has not lived up to expectations. That is why it has been extended, so that a length of 3.2 kilometres, and a high of 5 meters defended the Channel Tunnel, thereby the fence became nearly unbeatable. A barbed wire fence was set up and equipped with CCTV and infrared sensors and continuous patrols were also launched. Despite this, the authorities were not able to handle the increasingly stressful situation, so in August 2015, as a further strengthening, 500 police officers were deployed-both British and French-to safeguard the frontier zone. [27] According to the tunnel's operators, the fence was successful, [20] but a further construction of a new wall was again reported in September 2016. [28]

\section{Border Control of the Baltic States}

The Baltic states' motives are not necessarily tied to migratory pressures. While tightening border security is conducted in parallel with border provisions of the other states, their measures are linked to the deteriorating relationship between Russia and Western states, as well as the sensed political pressure of Russia on the Baltic Sea. [29] However, it is not insignificant that immigrants to Europe tried to reach the Schengen area through Russia from 2014, and onwards, creating another reason for which increased border control was necessary for the Baltic states (especially Estonia and Latvia). [30]

Estonia announced a structure in August 2015, scheduled to be an about 108-kilometre long and 2.5-meter tall barbed wire fence on one-third of its border with Russia. Enhancing the protection of the fence with a variety of radars and cameras, as well as motion detection systems, the fence will be one of the best-guarded installations, also including the planned use of unmanned aircrafts. The project costs more than EUR 70 million for the Estonian government. [31]

Latvia also announced the raising of a 90-kilometre long fence in 2015, aiming to reduce border crossings. By the end of the year a total of 10 kilometres of the planned fence was completed, while the remaining $80-\mathrm{km}$ section is planned to be constructed in 2018 . The security line has a defence purpose against trafficking, migration and the pressure presented by Russian foreign policy. The Latvian government budget allocated the amount of EUR 20 million for the fence. [32] 


\section{Hungary and the Southern Closure of the Borders}

The government of Hungary ordered the closing of the southern border on the $17^{\text {th }}$ June, 2015 , because of the hardly manageably threats from the south. The Parliament, on the $6^{\text {th }}$ July, 2015, adopted the 213/2015. (VII. 31.) resolution, according to which the area and the concept of the "temporary security closing of borders" were also accepted. According to this "the temporary security closing of borders: the facility owned by the State, which is located in the area under paragraph 1 and constructed in order to protect the order of the state border." [33]

The structure was built by the Hungarian Defence Forces, the closure of the Hungarian-Serbian border region stretches about $170 \mathrm{~km}$, as planned it was completed on the $17^{\text {th }}$ September, 2015. It is a four-meter high barbed wire fence with deployed military-police patrols. On the Hungarian-Croatian border section, the planned 105 kilometres was completed on $21^{\text {st }}$ October, 2015. In parallel with strengthening the borders, migratory routes gradually refocused, so after the closure of the borders, the Serbia-Croatia-Slovenia-Austria route took over the role of the original Western Balkans' migratory route (Serbia-HungaryAustria). According to data presented by the Hungarian Police on a monthly basis in 2015, the number of illegal immigrants decreased significantly since the completion of the fences. [34] The border wall was therefore a top priority for reducing the number of migrants arriving in Hungary, which is not only seen as a fundamental national defence task of the government, but an initial step in the revival of the failed (but extremely useful) Dublin Regulation III control system.

\section{Macedonia}

In November 2015, Macedonia also ordered a tightening of border security in the areas bordering with Greece. [35] Its primary aim was to check the large number of migrants from the unstable regions of the Middle East (mainly Syrians, Iraqis and Afghans). Following strengthened border controls, the government ordered a ban on migrants from Afghanistan, Pakistan, Iran and the African states and prescribed a requirement for increased control of Syrian and Iraqi migrants. The border controls were tightened further in January 2016, and at the request of Slovenia, they closed the western border of the country.

However, this step resulted in an increasingly chaotic situation among the continuously increasing amount of residents in refugee camps in Greece, where thousands of migrants wanted to cross indirectly to Macedonia. Among them, the settlement of Idomeni soon emerged, which formerly served as a staging point, prior to crossing the border. The facility became Europe's largest refugee camp in a few weeks. The inmates of various nationalities also repeatedly clashed among themselves and with local people and the Macedonian law enforcement agencies. The tense situation was resolved in May 2016, when the Greek forces closed refugee camps and evacuated the 8,500 residents from the area immediately. [36] Meanwhile, the country launched the establishment of a second, parallel fence on the Greek border that aims to continue the management of the migrant situation in the country. [37] 


\section{Austria, Slovenia, Croatia}

After the completion of the fence on the Schengen border of Hungary, Austria-although previously sharply criticizing the Hungarian construction-also announced the closing of the Slovenian-Austrian border, not aiming to discourage migrants, but to direct them towards the checkpoints. [20] Since the closing of borders in Hungary the guided migratory wave went through Croatia and Slovenia to Austria, a significant number of migrants arrived suddenly in these countries.

Austria ordered the setting up of a "gate" (fence) in November 2015, however, the government emphasized that passing through Austria remains an open possibility. The "gate" meant a 4-kilometre long 2.2-meter high fence on the border with Slovenia at Spielfeld, completed by the reported deadline. [32] In July 2016, another fence's construction plan was announced in Austria, now stretching 100-kilometre long by the Hungarian border, which only comes into effect if a similar migration pressure to 2015 develops. [38]

In November 2015 Slovenia also began closing some sections of the border with Croatia-near Veliki Obrez for example. [39] The wire fence was also prepared by the scheduled deadline. The President, Miro Cerar claimed that they do not want a hermetic closure of the borders, but their aim is to navigate refugees in the right direction. [35]

\section{Norway}

Norwegians are also considering steps to curb illegal border crossings coming from Russia, similarly to the Baltic States. Although the migration pressure decreased significantly based on data from Norwegian Immigration (UDI), [40] the government announced in August 2016, that during the year, a 200-meter long and 3.5-meter high fence is to be raised at the Schengen area's northernmost crossing point, in Storskog. Although many people criticize the fence construction, its size is dwarfed by the 196-kilometre long common border fence built by the Russians. [41]

\section{Conclusion}

The examples presented also show that the country's have not found a single universally applicable and internationally recognized, and in all aspects accepted management method for the recent security challenges. The issue of setting up physical barriers is often conflicted with humanitarian principles (for example integration and protection of refugees), even though the primary purpose of which would be precisely to protect those human values and central principles that are the foundations of the rule of law and the international community. However, due to rarely experienced mass migration and radical organizations' expansion, local solutions cannot be managed without international backing. Because of the security risks they create, collective and effective control methods should be developed both on national and international levels. Closing the borders, strengthening border controls in Europe today aims to limit the complex processes and the emerging cross-border threats with a historically recallable and many times proven-to-be successful tool. Because of the asymmetric threats, transnational organized crime, infiltration of members of terrorist organizations as well as 
threats from the East, liberalized border crossing conditions are difficult to control and not applicable for the effective preservation of today's security level. Setting up border walls and reviving controlled immigration methods however, can led to a reduced number of similar, security-hindering processes. We must see that countries mentioned in the analysis do not only strengthen border control for self-interests, but also to protect other European countries, existing administrative and social structures as well as European regional stability and security. However, whether these old-new methods will be effective and durable we may not yet know...

\section{References}

[1] COLLINS, R., McINTOSH, F.: Life in the Limes: Studies of the people and objects of the Roman frontiers. Barnsley: Oxbow Book, 2014.

[2] VISY Zs.: A római limes Magyarországon. Budapest: Corvina Kiadó, 1989.

[3] TURNBULL, S.: The Great Wall of China 221 BC-AD 1644. London: Bloomsbury Publishing, 2012.

[4] TARJÁN M. T.: A berlini fal ,alapkőletétele”. Rubicon Online. www.rubicon.hu/magyar/ oldalak/1961_augusztus_13_a_berlini_fal_alapkoletetele/ (Downloaded: 2803 2017)

[5] 'Laser walls' activated along India-Pakistan border to plug gaps in vigil. The Times of India, Apr 27 2016. http://timesofindia.indiatimes.com/india/Laser-walls-activated-along-IndiaPakistan-border-to-plug-gaps-in-vigil/articleshow/52012679.cms (Downloaded: 2803 2017)

[6] CANNON, B. J.: Terrorists, Geopolitics and Kenya’s Proposed Border Wall with Somalia. Journal of Terrorism Research, 72 (2016), 23-37. http://jtr.st-andrews.ac.uk/ article/10.15664/jtr.1235/ (Downloaded: 2803 2017) DOI: http://doi.org/10.15664/jtr.1235

[7] MWITHI, L.: Desperate Tunisia joins Kenya in building wall to keep out terror merchants. Mail \& Guardian Africa, 08 Jul 2015. http://mgafrica.com/article/2015-07-08-desperatetunisia-joins-kenya-in-building-border-walls-to-keep-out-terror-merchants (Downloaded: 28 03 2017)

[8] CARTER, D. B., POAST, P.: Why Do States Build Walls? Political Economy, Security, and Border Stability. April 5, 2015. www.princeton.edu/ dbcarter/David_B._Carter/Research_ files/walls_JCR_final.pdf (Downloaded: 2803 2017) DOI: https:// doi.org/10.1177/0022002715596776

[9] TOMLINSON, S.: World of walls: How 65 countries have erected fences on their borders - four times as many as when the Berlin Wall was toppled - as governments try to hold back the tide of migrants. Mail Online, 21 August 2015. www.dailymail.co.uk/news/ article-3205724/How-65-countries-erected-security-walls-borders.html\#ixzz3wNbhDWwR (Downloaded: 2803 2017)

[10] NIANE, D. T. (Ed.): General History of Africa IV. Africa from the Twelfth to the Sixteenth Century. Paris-London-Berkeley: Heinemann, 1984. http://unesdoc.unesco.org/ images/0018/001842/184287eo.pdf (Downloaded: 2803 2017)

[11] RONGXING, G.: Territorial Disputes and Resource Management: A Global Handbook 2007. New York: Nova Science Publishers Inc., 2007.

[12] ANDREW, C. H.: The Forgotten Frontier: A History of the Sixteenth-century Ibero-Africa Frontier. Chicago-London: University of Chicago Press, 1978. 
János BESENYŐ: Fences and Border Protection - The Question of Establishing Technical Barriers in Europe

[13] PINOS, J. C.: Building Fortress Europe? Schengen and the Cases of Ceuta and Melilla. 2009. www.qub.ac.uk/researchcentres/CentreforInternationalBordersResearch/Publications/ WorkingPapers/CIBRWorkingPapers/Filetoupload,174398,en.pdf (Downloaded: 2803 2017)

[14] Amnesty International: Fear and fences, Europe's approach to keeping refugees at Bay. London: Amnesty International Ltd., 2015. www.amnesty.eu/content/assets/Doc2015/2015_ Documents/Report_-_Fear_and_Fences-EMBARGO.pdf (Downloaded: 2803 2017)

[15] European Commission (EC): Report from the Commission to the European Parliament, The Council, The European Economic and Social Committee and the Committee of the Regions. Brussels: EC, 2014. http://ec.europa.eu/dgs/home-affairs/e-library/documents/policies/ borders-and-visas/schengen/docs/com_2014_235_f1_report_from_commission_en.pdf (Downloaded: 2803 2017)

[16] BESENYŐ J.: Nyugat-Szahara és a migráció. Afrika Tanulmányok, V különszám (2011), 35-45. www.afrikatanulmanyok.hu/application/essay/990_1.pdf (Downloaded: 2803 2017)

[17] Amnesty International: The human cost of fortress Europe - Human rights violations against migrants and refugees at Europes's borders. London: Amnesty International Ltd., 2014. www.amnesty.ch/de/themen/asyl-und-migration/festung-europa/dok/2015/die-kampagnesos-europa/bericht-the-human-cost-of-fortress-Europe (Downloaded: 2803 2017)

[18] FRAN Quarterly, 3 (2012), 1-74. http://frontex.europa.eu/assets/Publications/Risk_ Analysis/FRAN_Q3_2012.pdf (Downloaded: 2803 2017)

[19] European Council on Refugees and Exiles (ECRE): Frontex: detections for unauthorised border crossings hit record low in 2012. Brussels: ECRE, 2013. www.ecre.org/frontex-detections-forunauthorised-border-crossings-hit-record-low-in-2012/ (Downloaded: 2803 2017)

[20] BACZYNSKA, G., LEDWITH, S.: How Europe built fences to keep people out. Reuters, April 4, 2016. www.reuters.com/article/us-europe-migrants-fences-insightidUSKCN0X10U7 (Downloaded: 2803 2017)

[21] LYMAN, R.: Bulgaria Puts Up a New Wall, but This One Keeps People Out. New York Times, April 5, 2015. www.nytimes.com/2015/04/06/world/europe/bulgaria-puts-up-a-newwall-but-this-one-keeps-people-out.html\# (Downloaded: 2803 2017)

[22] KRASIMIROV, A., TSVETELIA, T.: Bulgaria to extend fence at Turkish border to bar refugee influx. Reuters, Jan 14, 2015. www.reuters.com/article/us-bulgaria-turkey-fenceidUSKBNOKN1JG20150114 (Downloaded: 2803 2017)

[23] FRAN Quarterly, 1 (2016), 1-33. http://frontex.europa.eu/assets/Publications/Risk_ Analysis/FRAN_Q1_2016_final.pdf (Downloaded: 2803 2017)

[24] BURROWS, T.: Return of the Iron Curtain: Soviet-era barbed wire fence is rebuilt in Bulgaria to prevent migrants reaching Europe via new Turkish route as Prime Minister also announces plans for a wall on Greek border. Mail Online, 25 March 2016. www.dailymail. co.uk/news/article-3509429/Return-Iron-Curtain-Soviet-era-barbed-wire-fence-rebuiltBulgaria-prevent-migrants-reaching-Europe-new-Turkish-route-Prime-Minister-announcesplans-wall-Greek-border.html (Downloaded: 2803 2017)

[25] Why is there a crisis in Calais? BBC News, 3 October 2015. www.bbc.com/news/uk29074736 (Downloaded: 2803 2017)

[26] Britain to offer NATO summit security fences against migrants. World Bulletin, 07 September 2014. www.worldbulletin.net/calais/143912/britain-to-offer-nato-summitsecurity-fences-against-migrants (Downloaded: 2803 2017) 
János BESENYŐ: Fences and Border Protection - The Question of Establishing Technical Barriers in Europe

[27] Calais migrants: How is the UK-France border policed? BBC News, 3 March 2016. www. bbc.com/news/uk-33267137 (Downloaded: 2803 2017)

[28] BRITTON, B.: 4UK to build 'big new wall' in Calais to stop migrants. CNN, September 7, 2016. http://edition.cnn.com/2016/09/07/europe/calais-wall-migrants/ (Downloaded: 2803 2017)

[29] RETTMAN, A.: Security fears prompt fences on EU-Russia border. Euobserver, 28 Aug 2015. https://euobserver.com/justice/130037 (Downloaded: 2803 2017)

[30] SYTAS, A., MARDISTE, D.: Worried over refugees, Baltics begin to erect border fences. Reuters, Mar 8, 2016. www.reuters.com/article/us-europe-migrants-balticsidUSKCNOWA1JN (Downloaded: 2803 2017)

[31] 'Great Estonian Wall:' Country decides to cut itself off from Russia ... with 2.5-meter fence. RT News: 17 Mar 2016. www.rt.com/news/336000-estonia-russia-border-wall/ (Downloaded: 2803 2017)

[32] Russia-Latvian Border Fence. Globalsecurity.org, 2015. www.globalsecurity.org/military/ world/europe/lv-russian-fence.htm (downloaded: 2803 2017)

[33] 213/2015. Regulation (VII. 31.). Korm. rendelet a határőrizeti célú ideiglenes biztonsági határzár építésén dolgozók védelmérôl, továbbá az államhatárról szóló törvény szerinti közérdekű használati joggal összefüggő kártalanításról szóló 211/2015. (VII. 23.) Korm. rendelet módosításáról.

[34] Elfogott migránsok száma. police.hu, (s.d.) www.police.hu/hirek-es-informaciok/hatarinfo/ elfogott-migransok-szama-lekerdezes?honap\%255Bvalue\%255D\%255Byear\%255D=2015 \&honap\%255Bvalue\%255D\%255Bmonth\%255D=10 (Downloaded: 2803 2017)

[35] BACHELOR, T.: The New Iron Curtains: Where the fences are going up across Europe to keep migrants out. Express, Dec 6, 2015. www.express.co.uk/news/world/624488/Europeborder-fences-migrant-crisis (Downloaded: 2803 2017)

[36] KINGSLEY, P.: Idomeni: Greek riot police move in to clear refugee camp. The Guardian, 24 May 2016. www.theguardian.com/world/2016/may/24/idomeni-greek-riot-police-movein-before-dawn-to-clear-out-refugee-camp (Downloaded: 2803 2017)

[37] Europe builds another wall: Macedonia erects second barrier of razor wire to stem the human tide from Greece. Mail Online, 8 February, 2016. www.dailymail.co.uk/news/article3437717/A-second-wall-razor-wire-stem-human-tide-Macedonia-builds-fence-borderGreece-send-message-migrants-attempts-cross-illegally.html (Downloaded: 2803 2017)

[38] Austria ready for $100 \mathrm{~km}$ border fence with Hungary. The Local, 22 July 2016. www. thelocal.at/20160722/austria-finishes-preparing-100km-border-fence-with-hungary (Downloaded: 2803 2017)

[39] SURK, B.: Slovenia Builds Border Fence to Stem Flow of Migrants. New York Times, Nov 11, 2015. www.nytimes.com/2015/11/12/world/europe/slovenia-border-fence-migrantsrefugees.html?_r=0 (Downloaded: 2803 2017)

[40] Statistics on Immigration. UDI, 2016. www.udi.no/en/statistics-and-analysis/statistics/ (Downloaded: 2803 2017)

[41] Norway to build fence on border with Russia to curb refugee inflow. RT News, 24 Aug, 2016. www.rt.com/news/357061-norway-fence-russia-refugees/ (Downloaded: 2803 2017)

[42] Altai Consulting/IOM MENA Regional Office, 2015.; UNDOC, 2013.; Migreurop/Gadem, 2015.; Frontex, 2016. 